\title{
"Comfort without offence"? The Performance and Transmission of Exile Literature at the English College, Valladolid, 1592-1600 ${ }^{1}$
}

\author{
BERTA CANO ECHEVARRÍA \\ University of Valladolid, Spain \\ ANA SÁEZ HIDALGO \\ University of Valladolid, Spain \\ GLYN REDWORTH
}

The University of Manchester, UK

MARK HUTCHINGS

University of Reading, UK

Parmi les séminaires établis après la Réforme, le Collège de St-Alban de Valladolid a joué un rôle politique et religieux particulièrement significatif. Dès ses premières années, la couronne espagnole a démontré son soutien envers le Collège des Anglais, et exprimé ses objectifs à travers une série de visites royales. Chaque visite était différente, mais elles ont en commun le fait que le collège a souligné ces occasions au moyen d'une commémoration riche du point de vue littéraire et imaginative. Des poèmes et des emblèmes étaient affichés sur les murs et récités par les séminaristes, et des récits ont par la suite été imprimés et ont circulé en anglais et en espagnol pour faire connaitre publiquement ces célébrations et ainsi réaliser leurs buts politiques et religieux. Cet essai examine les premières années d'existence du Collège des Anglais de Valladolid, en situant son rôle dans le contexte politique, religieux et culturel, et en se concentrant sur les événements dont le collège a été la scène, et qui ont été diffusés sous forme imprimée dans les toutes dernières années $d u \mathrm{XVI}^{e}$ siècle.

$\mathrm{R}$ ecent studies have revisited the issue of religious identity in early modern England, emphasizing both its wide-ranging significance and its complexity; however the literature of exile has largely been absent from this debate. ${ }^{2}$ The situation for Catholics in England was not of course one of absolute isolation. Indeed, historians have demonstrated how ideas and influences from beyond England's shores played a key role in sustaining "the old religion," the smuggling and suppression of priests and prints being both well documented. What is much less well known 
is the role religious seminaries played in this process, and in particular how communities in exile participated in the performance and dissemination of literature. This article examines the importance of one such seminary, and the place it has in the history of Anglo-Spanish relations in the late sixteenth century. What follows sheds light on a little-known but significant episode in these relations that in turn may inform our understanding of the position of English Catholic exiles in Spain during the last years of Elizabeth's reign.

The early years of St Alban's College at Valladolid were a time of acute tension between Spain and England. For Spanish courtiers and subjects alike, the presence of the seminary in Valladolid was a constant reminder of the persecution suffered by Catholics in England; for the English authorities, St Alban's College (like those elsewhere) posed a political and religious threat. Such was its importance to successive Spanish monarchs that on no fewer than four occasions the College hosted royal visits. Not only did these events generate considerable prestige for the College, but the surviving evidence indicates that the textual reproduction and transmission of the festivities had considerable ramifications for Anglo-Spanish relations.

These were complex events, combining a range of forms of literary expression. The procession and royal visits were commemorated by the production of poetry and emblems, chiefly (though not exclusively) written by students of the College, and designed to celebrate the feast given to honour the king. Although this material might be described as "ephemera," since it was disposed of after the event, we prefer the term "commemorative literature," for the event itself, or versions thereof, enjoyed a textual afterlife (in pamphlets) that preserved and disseminated the College's literary activities and (it will be proposed) highlighted their political and ideological significance. Following each royal visit or festivity, pamphlets were commissioned to record the occasion. These accounts collated some of the poetry and emblems composed for the celebration, framing the event in a narrative retelling and representation of the performance. Clearly one of their aims was to disseminate news of the royal event; but what is particularly interesting and of central importance in what follows is that in most cases these texts were produced in both Spanish and English versions. Thus it is that the activities of St Alban's College were both "local" performance events and, more importantly, texts re-presented and transmitted for a wider audience. Moreover, not only were the target audiences of these pamphlets different, but the texts themselves reveal interesting divergences in their rendering in different languages. As will be seen, this commemorative literature offers an interesting case study in how exile literature functioned, thus illuminating the kind of role a seminary might play in textual production and transmission. 
When in October 1591 a Royal proclamation against "seminarie priests and Jesuits" was issued by Elizabeth I, Spain's first English seminary had been established for only two years. ${ }^{3}$ Nevertheless, the contribution to the Catholic mission by St Alban's prompted William Cecil, the Lord Treasurer, to identify Rome and Spain as centres of exile intrigue:

\begin{abstract}
A multitude of dissolute young men, who have partly for lack of living, partly for crimes committed, become fugitives, rebels and traitors, and for whom there are in Rome and Spain and other places certain receptacles made to live in and there to be instructed in school points of sedition and from thence to be secretly and by stealth conveyed into our dominions. 4
\end{abstract}

Robert Persons, the founder of the College, and Cardinal William Allen, his counterpart in Rome, are singled out in the Proclamation, and both are portrayed as the traitorous organizers of Catholic resistance to Queen Elizabeth's Protestant regime. According to the Proclamation, Philip II was using a religious-political strategy to conquer England after the failure of the Armada three years previously.

The College's position in Spain was complex. Although in 1592 a foundational papal bull declared the school to be subject to the papacy, it never became a pontifical school like the College at Rome but remained dependent on the Spanish Crown and was run by the Jesuits. According to Persons, this was the only administrative formula which would allow the English colleges to prosper in Spain.5 Such varied sponsorship kept them relatively safe from the Inquisition and from more general suspicions about their "Englishness," something that in Spain a priori classified them as potential heretics and spies. ${ }^{6}$

St Alban's students could obtain degrees in Arts, Theology, and Philosophy similar to those granted in Oxford or Cambridge, but they took their tuition together with Spanish students at the Jesuit college of San Ambrosio. This arrangement, on top of the fact that a Spanish Jesuit was imposed as rector, was not popular among the English. It seemed at odds with the missionary aims as well as the cultural peculiarity of St Alban's. The College nonetheless flourished, and the number of students increased rapidly, Cecil's proclamation inadvertently providing welcome publicity. ${ }^{7}$ Also, the students' growing reputation as heroes and victims of heretics meant that the College became an important new institution in Valladolid.

After receiving holy orders, the new priests were to return to their country to champion Catholicism - and to a possible martyrdom. The journey was difficult and dangerous, as the priests had to travel incognito, disguised as soldiers, or merchants, with a small sum of money or viaticum donated by the Spanish Crown or from alms the students had collected. Their mission usually ended with capture, sometimes 
as soon as they reached the English coast, as in the case of Henry Walpole in 1595 who was arrested together with his two companions within hours of landing in Yorkshire. ${ }^{8}$

However, failure was not invariably the outcome and their activities were greatly feared by the English authorities. Thus their image among English Protestants was rather different, as expressed in the Proclamation of 1591:

[They are] unnatural subjects of our Kingdom ... who renounce their natural allegiance due to us and our crown, and upon hope by a Spanish invasion to be enriched and endowed with the possessions and dignities of our other good subjects. ${ }^{9}$

To counteract this, and promote their own version, stories such as the martyrdom of Henry Walpole or the Royal Visits to the College provided ideal propaganda material for the English mission. Colleges were obviously ideal places to produce pamphlets and poems to commemorate the efforts to reconvert England. This commemorative literature thus needs to be contextualized not only in this atmosphere of persecution and propaganda but also in terms of the border-crossing between cultures and languages which are a key feature of this early modern exile literature.

\section{Public celebrations, poetry, and pamphlets}

When Philip entered London in 1554 as England's new king and husband of Mary Tudor, the union was honoured with an elaborate succession of devices that served to both pay tribute and deliver a complex message from the city to its new monarchs. This royal procession consisted mainly of built structures and triumphal arches to stage a variety of pageants, verses, and paintings evoking variously English history, royal genealogy, and classical myths. ${ }^{10}$ The tradition of civic royal entries with occasional architecture and festive activities had extended throughout most countries in Europe, but not all of them established the same patterns of celebration. While English triumphal processions and academic royal entertainments gave a central space to theatre and dramatized pageants presented by actors, in Spain the emphasis was on the display of verse and visual poetry.

The development of occasional poetry in Spain was closely related to the tradition of public festivities. For this type of occasion, poetry was normally written to decorate the route of the procession and was prominently placed on ephemeral architecture, such as commemorative arches or catafalques as well as other mural decorations. Since text and image worked together, the poetry used for these occasions was visual in character, written out following various patterns or in the form of acrostics, labyrinths, or emblems. The poems could be displayed in any number 
of picturesque forms, such as flowers painted on the ground, birds holding ribbons with printed poems, large cards carried by children or by people carrying them on their backs; decorated chariots, pyramids, altars, and even poems thrown from a chariot. ${ }^{11}$ However, the tone of academic or more learned celebrations was rather more sober and, although the idea of decorating the trajectory of the guest of honour with poetry was maintained, its forms, disposition, and contents were designed to convey discretion and erudition. ${ }^{12}$

Hitherto, a major difficulty for the study of the relationship between poetry and celebration in the Spanish tradition has been the scarcity of graphic reproductions revealing how text combined with image. ${ }^{13}$ The poetry as well as the ephemeral architecture was specifically created for the occasion and usually it disappeared once the event had taken place. It is only thanks to the relaciones de fiestas that we have witness accounts of what the ceremonies were like. In a few of them we can see illustrations and occasionally some engraving or etching of the most striking poems or monuments, but in most cases the compiler omits the illustrations and offers only the verbal descriptions of the visual part of the celebration. This exclusion had much to do with the cost of printing illustrations, but we also have to consider the haste involved. Engraving images was time consuming and would delay publication and dissemination of the relaciones. For this reason the relaciones are usually incomplete: this is because we only have the text of the emblems (the inscriptio and the descriptio), the pictura or figure is normally replaced by a written description. Moreover, typically writers made only a selection from the poems available, leaving some out, opting for shortness.

Recent studies in early modern pageantry have focused mainly on how power relations between sovereign and subjects could be visually displayed through the performance of public events. Thus, royal entries and other such processions and progresses have been understood as mainly propagandist in function, "strategies for idealising power,"14 though their success among the audiences targeted has been disputed. ${ }^{15}$ Accordingly, the royal visits and processions concerning the English College can be interpreted as acts of propaganda performed by the monarchs and their entourage to show support for the English Catholic cause; however, our interest is in the other agents of the celebration, the seminarists, and how they made use of royal authority for their own propaganda purposes. In fact, the commemorative literature that has come down to us was either written by members of the College or subsidized by it, so it is important to pay particular attention to this aspect of textual production. It is also necessary to make a clear distinction between the intended target audiences of each of the texts as well as the different 
times of composition, and explore how these features function as key elements for understanding commemorative literature. Therefore, two stages will be considered: first, the moment of celebration itself, with the poetry composed and displayed for the occasion; and second, the rendering of this material into a narrative text for distribution. The matter is further complicated by the fact that these texts were transmitted both to English and Spanish audiences, thus problematizing the concept of a single rendering, not only because the language changed, but also because these distinct audiences, at certain moments, had radically divergent interests and perspectives. While during the celebration the monarch's support was sought, as is shown in the panegyric poetry, the Spanish narratives seek to manipulate this support and offer it to readers as a sign of prestige and an example to follow. However, in the case of the English accounts, the texts are at least potentially treasonous from the point of view of the law of England, and the authors had to be sensitive to a number of prejudices and fears about Spain and Spanish monarchs, even from English Catholic readers. ${ }^{16}$

\section{The visit of Philip II in 1592}

The first royal visit to the English College was a result of a progress in 1592, culminating in Philip II's summoning of a parliament at the Aragonese town of Tarazona. The journey had an obvious political purpose, but it also allowed for the strengthening of ties between the monarch and his people through the interchange of symbolic gestures. The royal train, which included Prince Philip and the Infanta Isabel Clara Eugenia, later governor of the Netherlands and Spain's candidate for the English throne, left El Escorial in May and made several stops in its progress to be acclaimed and variously entertained before it reached Valladolid on 27 June, where the court would remain for two months before departing for Zaragoza. The pamphlet $A$ Relation of the King of Spaines receiving in Valliodolid, and in the Inglish College of the same towne, in August last part of this yere is one of the written printed accounts of this journey, published in Antwerp in 1592. ${ }^{17}$ The Relation is anonymous, though it has been attributed to Robert Persons. This is improbable, however, for reasons of internal and external evidence ${ }^{18}$ that point strongly towards Joseph Creswell SJ, who had recently arrived from Rome and would later become the author of a considerable number of pamphlets connected with the College, both in English and Spanish. ${ }^{19}$

Leaving aside the problem of authorship, the pamphlet follows an epistolary form, with the author addressing an acquaintance living in exile in Flanders. Given 
the close generic relationship between semi-private letters and the still-developing news pamphlets of the era, it is impossible to know whether the 62 pages of the printed pamphlet were initially intended as a private letter, or whether this was simply a literary device. Since the pamphlet was published in Antwerp, a centre for the English Catholic book trade, it was clearly convenient to send the account there. ${ }^{20}$

In the text's opening the narrator comforts the addressee of the letter, who has been forced to leave England after hiding a Catholic priest in his home. This is a clear reference to the Proclamation of 1591, where for the first time the "diet, lodging and residence in their house" ${ }^{21}$ of seminary priests was banned, and contextualizes this pamphlet as among the numerous written responses issued at the time. ${ }^{22}$ The pamphlet relates the circumstances of the foundation of the College in Valladolid, a particularly important point because it refutes accusations in England that it was part of a wider plot (Creswell, 7). This first part of the pamphlet has attracted the greatest attention, as it is regarded to be the earliest and most authoritative document concerning the foundation of English seminaries in Spain. ${ }^{23}$

In what follows, two related events are narrated: Philip II's journey to Valladolid and his visit to the English College. The royal visit was intended to emphasize Valladolid's privileged position among the cities of Castile: "among all the places of this kingdome of Castilla la Vieia, this towne of Valliodolid, ... [is] the principall both for the royall chauncerie, Tribunal of Inquisition, honor of Universitie, residence of nobilitie, \& other preheminences" (Creswell, 16). The most detailed section naturally concerns the royal visit. Not only is it separated from the previous text by the title "Of the Kinges coming to the Inglish College" (Creswell, 21), but it takes up the largest part of the Relation. The writer explains how Philip took the unexpected decision to attend personally, something "which before they never durst to have expected, \& much lesse to have requested" (Creswell, 21). Everything had to be hurriedly prepared. The buildings had to be finished and the walls decorated with coloured drapery which in turn displayed the verses composed for the occasion. The College walls were "adorned with abundance of verses of manie languages, emblemes, hieroglyphicks, and other learned inventions, as was most beautifull and delectable to behold" (Creswell, 24).

The students waited for the arrival of the king and his retinue at the entrance; then the whole party went into the chapel to pray, before proceeding to the main hall, where they listened to the orations and discourses prepared by the students. Here the king was compared with the prophet Abdias who had saved 100 Hebrews from the persecution of Queen Jezebel (Elizabeth I was referred to as a Jezebel throughout Catholic Europe). But the most notable event of the celebration from 
the narrator's point of view was an oration in ten languages. In this exercise ten students recited ten consecutive verses from Psalm 71, commenting on them, each in a different language. The oration started with Hebrew "as mother and roote of all the rest" (Creswell, 32), followed by the "learned tongues," Greek and Latin, the “vulgar languages," English, Welsh “or Brittish” and Scottish, then the Romance languages, French, Italian, and Spanish, and finally Flemish (Creswell, 36, 41). The Jesuits were keen to show their linguistic mastery, and with this exercise the students demonstrated not only their knowledge of ancient and modern languages but also the College's vocation as a supranational institution:

And for that the superiours of this house consydering the good abilitie of theis students, in the varietie of languages, which in this banishment of theirs they have learned, being able to speake and write verie perfectlie in nyne or ten different tongues (a rare thing as it seemeth in a College of one onlie Nation) they thought it best that in everie language some schollers shold take a verse of the foresaid Psalme. (Creswell, 25)

The writer dedicates a considerable amount of space to this exercise, describing the appearance, origin, and academic training of each of the participants, omitting their names in order to protect their families. ${ }^{24}$ In some cases we have an almost literal transcription of some passages of the commentary in the original language, as for example with French, Italian, and Spanish; elsewhere the author paraphrases or summarizes the content, peppering it with comments about the reactions of the king and the rest of the audience, the nature of each of the tongues, or the students' ability. To conclude this part of the proceedings a student delivered a final oration in praise of the king. The ceremonies so impressed the monarch that before he left the College after nightfall he addressed the students individually.

After the king's farewell the pamphlet makes the point that the Marquis of Velada ordered all the verses decorating the walls of the College to be collected and sent to Prince Philip's tutor so that the heir to the throne could have the opportunity of examining them in more detail:

which was done, but yet with somme choise for that in the whole multitude was so greate as it was thought wold have ben tedious, for the number of the sheetes of paper were esteemed above two hundred in all, wherein besydes all kind of verses, in all the foresaid ten sorts of languages, there were manie other ingenious devices (as I have said namelie of Emblemes, \& Hieroglyphicks). (Creswell, 52)

Velada's chance intervention is crucial to our understanding of the sophisticated interplay in commemorative literature between printed texts and the ephemeral literature which was normally intended only to last for the duration of the ceremonies. 
It would appear that a unique manuscript with original emblems in the Biblioteca Nacional in Madrid (BNM, MS 2492) corresponds to this selection of poems; the fact that it has fourteen Latin emblems with their corresponding images plus a diversity of other poems, all of which are dedicated to the Prince, persuades us that it is related to this celebration. ${ }^{25}$

After mentioning the Marquis of Velada's intervention, the pamphlet turns its attention to a description of five hieroglyphics. The author relates how after the king's visit, various members of the nobility visited the College themselves, and being very favourably impressed, they gave money to St Alban's. The pamphlet concludes by predicting the prompt success of the English Mission and by launching a curse of sorts upon William Cecil, Lord Burghley, his family and descendants. ${ }^{26}$ This is a further proof of the direct relationship between the pamphlet and the Proclamation, as Cecil was widely understood to be the author of the 1591 edict. Indeed, the curse on Elizabeth I's chief minister was an indirect means of cursing the queen herself, something which otherwise would have made the book unacceptably libellous as an act of treason.

The same year as Creswell's English text was published, a Spanish version was printed in Madrid. That the Relacion de un sacerdote ingles, escrita a Flandes a un cavallero de su tierra, desterrado por ser catolico ${ }^{27}$ was based on the previous text is clear from the title page where it is said to have been "translated from English into Castilian by Tomas Eclesal, English gentleman.. ${ }^{28}$ The way for a Spanish translation was already prepared in the English original:

And manie copies of the same [hieroglyphs] were demanded which will inforce (as I supposed) the superiors of this College to put the whole in printe or at least wise the chief points thereof, with a larger and more particular narration of all in the Spanish tongue then this is, which no doubt will be verie grateful unto this nation, for that thereby they shall not onelie see what passed in this acte of the Kings coming hither, but also further understand manie things of the present state of Ingland. (Creswell, 57-58)

This passage is important for two reasons. First, it shows how commemorative literature was viewed as important and sophisticated enough to be subtly adjusted for the benefit of a target audience different from English Catholics. Second, the reference to "a larger and more particular narration" strongly suggests that translation was understood not in the narrow sense of a word-for-word rendition, but rather in the more fluid sense of being based on an earlier text and pitched at the interests of a primarily Spanish audience. Of course, as both author and translator were eye-witnesses of the event, each must have had their own perspective on what had transpired. ${ }^{29}$ 
Though the structure and content are essentially the same, there are substantial differences between them. Frequently, the differences have to do with interpolations that add information or explain certain details, introducing what appear to be the translator's own first hand observations. Some differences are significant. The final section, "About those who now part from the English College to the mission in England" 30 is new to this version and recounts the audiences that Philip II and Prince Philip each gave to the four recently-ordained priests from the College who were about to depart for England. All the students had to take a missionary oath as seminarists, and the writer explains to his Spanish readers that twelve priests had already been sent the previous year. By way of conclusion the translator omits the curse upon Cecil and instead explains the important role of the papacy as the sponsor of the English Mission and protector of the English Colleges on the Continent, a reference presumably being considered more significant to Spanish readers than an attack on a foreign minister.

\section{Image and Text in 1592}

Of the 200 poems the author estimates were written for the occasion of the royal visit of 1592, we again have only a partial selection, and, intriguingly, in each of the versions (the two pamphlets and the "Prince manuscript") the selection is different. In the English version the choice is reduced to only five hieroglyphics, as they are called by the writer, whereas the Spanish version offers the same selection but adds five more and a number of poems written in different languages. The Prince manuscript goes further, offering fourteen new hieroglyphics interspersed with other poems. The conclusion must be that these three documents differed in their selection because each version was felt to be worthy of fine-tuning according to perceived differences in the target audiences. Thomas Eclesal even explains the reasons behind his choice. He took into consideration the language as well as following the advice of the English author:

I looked at all the poems in the ten languages and chose those that I thought would be more easily understood here, and these are, apart from the Spanish, that is understood by everyone, the Latin and the Italian. And so I decided to include from these three some of the hieroglyphs and poems, following in this the counsel of the priest that wrote in English. ${ }^{31}$

It is from this passage that we learn that the poems followed the same spirit of multilingualism as the oration to the king, with the same ten languages used in the composition of hieroglyphics and other poems. 
The emblems that appear in the printed pamphlets all follow the same layout of "emblem without the emblem." Each time, the absent picture is carefully explained, the inscriptio (always in Latin) is transcribed, and then the verses which follow are reproduced and where necessary translated into the language of the pamphlet. In the English selection we find that all the hieroglyphs represent the English Catholic exiles through various images — sometimes as victims and sometimes as heroes. They appear either as humans or animals, and they are diversely contextualized in settings of struggle and oppression. We will consider these five hieroglyphs in some detail to provide an idea of the schemes and symbols used in the celebration.

In the first emblem, the English Catholics are attacked by three lions while another, bigger lion wearing a Crown is protecting them and leading them back towards a Castle. Heraldic symbolism is present here both in the three lions (the English coat of arms) and in the castle (Castile). This is the only emblem where the epigram or descriptio as well as the motto is in Latin, which reads Eripio non Rapio, words attributed to the crowned lion and rendered by the author as "I take awaie to deliver and not to devoure" (Creswell, 52). This clearly signals that Spain's interventions in England are intended to restore Catholicism rather than deprive her of her liberty. The symbolism of the castle is also repeated in the second hieroglyph. The fortress is shown full of armour and weapons which hang from the windows while young men are depicted climbing ladders to reach those arms. Here the epigram that follows shows both a Spanish and an English version, and in it the belligerence of the iconic representation is softened as the arms are transformed into weapons of learning and virtue:

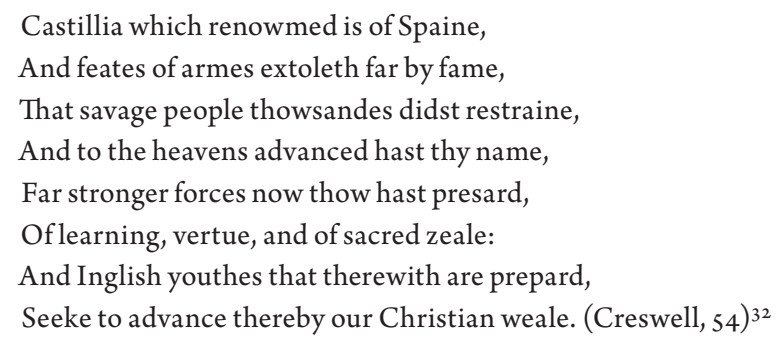

The third hieroglyph is once again inspired by heraldry. This time it is the flames of fire in the coat of arms of Valladolid which are set on one side of the picture while the other depicts an island. Two boats packed with English students carrying torches travel in opposite directions; in the boat leaving the island the torches are unlit, while the other boat shows the students carrying flaming torches. The verses 
that follow are both in Spanish and in English and express in the first-person plural the purpose of the students who travel to Spain

From countries far to kindle we are come,

Our darckned light in cleere celestiall flame,

And then againe with courage to returne,

The fyre of hell to vanquish with the same. (Creswell, 55$)^{33}$

This theme of catechism is also symbolized in the fourth emblem, but instead of flames to represent the faith we have grains of wheat carried by white pigeons to be sowed in another country, making use of a well-known animal symbolism; the pigeons are attacked by crows, but a crowned eagle sitting on top of a heap of wheat representing the Spanish monarchy is protecting them. Again a Spanish and an English version of the epigram follow the description of the icon and this time we find the royal eagle protecting the students:

The Royall Egle freely doth admitt,

You pigeons whyte, in his Iberian boundes,

The seede of learning and of skill you gett,

The which is sowed in the purest $\mathrm{g}[\mathrm{r}]$ oundes. $(\text { Creswell, } 56)^{34}$

The last hieroglyph of the English selection also presents more animal symbolism, although here the protecting figure of the King of Spain is replaced by the figure of Christ, who appears as a shepherd. The emblem shows a flock of sheep being attacked by wolves but, contrary to the other emblems, they are not defended by the shepherd, who stands watching the scene without intervening. The epigram that follows explains the reason for this apparent neglect:

O soveraigne pastor do thy flock regard,

In teeth and clawes of cruel beasts destrest

Yea so I do, and eftsones have I hard,

My sheepe lament, that are els where oprest.

Why let you them thus in the feild remaine

Where greedy wolves do suck their giltlesse blood?

Because in dying they get lyf againe,

That give their lyves for their poore countries good. (Creswell, 57)

Thus ends the English version, with the author referring to the interest the poetry aroused among the royal party. This is in itself an expression of the importance to contemporaries of commemorative literature, as is his call for a Spanish version which would include a wider selection of poetry (Creswell, 58). 
His plea was answered. In the Spanish version "Thomas Eclesal” starts his selection with the hieroglyphs and then classifies the rest of the poetry according to the different languages. The same five hieroglyphs mentioned above appear also in this collection (but only in Spanish), although in a different order with five more emblems and their Spanish epigrams added. In these emblems new motifs appear, mainly from the Scriptures. Noah, Daniel, or Joseph are represented in episodes that symbolize the life and struggle of the English exiles, something that gives the Spanish selection a far more religious and accordingly less "political" bias. The narrator explains that there were more he could have included and that he would have been pleased to have the paintings reproduced, but that there was "neither comodity, nor time for it." ${ }^{6}$ Following this we have 25 other poems in Latin, Italian, and Spanish. What is notable here is the variety of the forms-epigrams, sonnets, songs, and other learned stanzas such as a logogriph-all of which attest to the academic and literary achievements of the students. ${ }^{37}$ Most of them are preceded by dedicatories, some to His Majesty, others to the Prince or the Infanta Isabel, and among them is a description of how some poems had been displayed at the outer door on very large sheets arranged symmetrically above and at the sides of two of the main doors. At the entrance to the inner door there were poems in Latin, Greek, and Hebrew, as well as Spanish and English.

The third source of information, the Prince manuscript, is the most complete as regards the number and form of the poems, but it is also the most obscure about the circumstances that surround them. Scholars have not linked this remarkable collection of emblems to the English Seminary in Valladolid. In the manuscript in the Biblioteca Nacional, however, the title page clearly connects the poems with Prince Philip and the College: Epigrammata Serenissi Exellentissimoque Hispaniarum Principe Philippo $3^{\circ}$ Anglorum ob Catholicam fidem exulantium Maecenati opt. Suum Vallisoletanum Anglorum Collegium grati animi Argumentum. ${ }^{38}$ But no other information is provided, and what follows is a collection of emblems and diverse other poems where Prince Philip is repeatedly addressed or characterized. Curiously, no poem coincides with the ones selected in the English or Spanish pamphlets, a problem that could be explained by the fact that neither the writer nor the translator had these pieces to hand. The hypothesis that these poems correspond to the ones presented to the Prince at the request of his tutor is reinforced by the fact that they are all in Latin (except for one in Greek) which would enhance their pedagogical purpose. The unique character of this collection lies in the fact that, up to this point, they are the only extant pieces where the pictures of the emblems survive. This, together with the fact that they are hand-painted and coloured, makes them 
a unique source not only for the visit of 1592 but also for ephemeral decoration as a whole. Furthermore, there is the intriguing possibility that they are the original pieces that hung on the walls of the College, although this is perhaps unlikely due to the size of the pictures and the way they are bound in quires..$^{39}$

The Prince manuscript comprises 36 folios which contain fifteen emblems preceded by a coat of arms. Apart from the sixteen poems that accompany each of the illustrations, we have two acrostics, seventeen Latin epigrams, one Greek epigram, two songs, and two poems dedicated to the Prince. The collection is relatively homogeneous as regards topics and symbols, with cross references between the different compositions so that it has some of the flavour of an emblematic sequence. The most recurring symbol is that of the sun, which appears in half of the emblems manifesting its qualities of constant renewal, king of the heavens, and giver of life. Following this motif, most of the emblems refer to the natural world showing animals (4v-5r, 6v-7r, 13v-14r, 18v-19r, 26v-27r), ${ }^{\circ}$ plants $(12 \mathrm{v}-13 \mathrm{r}, 15 \mathrm{v}-16 \mathrm{r}$, $20 \mathrm{v}-21 \mathrm{r})$ or meteorological phenomena (10v-11r, 22v-23r, 31v-32r, 35v-36r). The first two emblems are closely related and are appropriate for opening the collection: both show two eagles, an adult and an eaglet close to their nest. In the first the eagle is making the eaglet stare at the sun, while in the second one he is teaching it to fly. The reference to Philip II and his education of the future Philip III is clear, but the emblemist adds a new meaning to this relationship between father and son, for the prince will prove to be a worthy son of his father if he follows his example in defence of the true faith. The notion that the eagle is the only bird able to stare directly at the sun - and thereby forces its brood to do so too-is present in other emblems of the Spanish canon, ${ }^{41}$ but only here is it applied to the royal family, where the rays of the sun symbolize the power of the Catholic faith.

The concept of renewal in the figure of the future Philip III is also present in other emblems: in one (18v-19r) he is pictured as a Phoenix reborn of his father, in another (10v-11r) he is the morning star announcing the imminent sun, evidently the restoration of the Catholic faith in England. The distinction between the prince and his father is blurred in other emblems that show the protection given by the Spanish Monarchy to English Catholics. This protection is presented through the symbols of the lion (13v-14r, 26v-27r, 29v-3or), the tree (15v-16r), or even a hand that holds firm a tree swayed by the wind ( $24 \mathrm{v}-25 \mathrm{r})$. Neither English Catholics nor heretics are represented in human form: in the emblem of pages $26 \mathrm{v}-27 \mathrm{r}$ their situation is portrayed as that of a lion cub being devoured by its mother-symbolizing, in one, heresy, England, and Elizabeth I-while a male lion (the Spanish monarch) is pulling it out of the lioness's jaws. A rose (12v-13r) and a flower (20v-21r), nourished 
by the sun, represent the English faith as well; the sun that spreads the odour of the rose $(12 \mathrm{~V}-13 \mathrm{r})$ also makes possible the rain that will fertilize the unproductive soil of their homeland (31v-32r). In this collection, the only emblem that shows a human figure depicts Hercules in the Garden of the Hesperides taking hold of the apples with the dragon slain at his feet $(33 \mathrm{v}-34 \mathrm{r})$. Although this emblem stands out because of the presence of this figure, mythological references, including one to Alcides or Hercules $(13 \mathrm{~V}-14 \mathrm{r})$, are present in other poems, though not portrayed in the pictura. Moreover, Hercules is the mythological character that appears most conspicuously in the Spanish emblematic tradition. The assimilation in this emblem of Hercules to Philip II is, then, original and it goes together with the identification of Hesperia with Spain as a blissful garden in a far west corner of the world.

\section{The visit of Philip III in 1600}

When in 1600 Philip III spent several months in Valladolid, he decided to visit the English College for a second time, though now as king rather than heir. The visit was of such importance to St Alban's that it was commemorated in a pamphlet printed in the same year: Relacion de la venida de los Reyes Catholicos al Collegio Ingles de Valladolid, en el mes de Agosto. Año de 160o. Unlike the occasion of the visit of 1592, the Relacion de la venida was composed in Spanish. Antonio Ortiz was commissioned to write the work, ${ }^{42}$ which was then immediately translated into English. ${ }^{43}$ Though it harked back to his father's visit eight years earlier, it is crucial to note that the pamphlet was written with a high degree of sensitivity to radically different political and religious circumstances. The year 1600 was a key historical and political moment for Valladolid. King Philip III was considering the possibility of moving the court back from Madrid; before doing so, he decided to spend some time there, meeting with civil and ecclesiastical authorities, going to churches and monasteries and studying its infrastructure. ${ }^{44}$

The Relacion de la venida differs from the 1592 texts in four significant ways: its original language, genre, structure, and the nature of the translation. Firstly (and most obviously) the choice of language indicates a different original target audience, compared with the pamphlet of 1592. This shift in emphasis (and in direction of translation) is a marker not only of the different circumstances but also of the complexity of these examples of commemorative literature. The second difference is the genre chosen for this pamphlet. Instead of the epistolary form used for the 1592 works, the writer appears to have been acquainted with the historical and literary nature of Spanish narratives of festivities and royal entrances, and accordingly 
adopted this model. True, the 1600 pamphlet is dedicated to the Infanta Isabel Clara Eugenia, ${ }^{45}$ and comments on the difficult religious situation in England are not addressed so directly here. This is presumably out of sensitivity to the Infanta's position, since she was now Spain's official candidate for a Catholic succession on the death of Elizabeth, and it would have been impolitic to stress the difficulties that lay ahead were she to be placed on the English throne.

Thirdly, while the 1592 narrative begins with a detailed account of the circumstances leading up to the celebration and then deals with the royal visit (only including the selected poems after these reports by way of an appendix), Ortiz follows a more chronological ordering. It begins with an introduction about the king's visit to the prospective new capital before turning to a meeting with Creswell and the students, preparatory to visiting the college itself (Ortiz, $1 \mathrm{r}-7 \mathrm{r})$. The reader is then informed of the arrangements for the festivities in a detailed section describing the ornaments, paintings, and disposition of the College chambers for the occasion (Ortiz, $7 \mathrm{v}-11 \mathrm{v})$, together with a large selection of the poems affixed to the walls (Ortiz, 12r-28v). Only then is the narrative resumed, with a meticulous account of how the celebrations themselves took place (Ortiz, 28v-49v).

This ordering illustrates a wholly different conception of the Relacion de la venida as commemorating a newsworthy event, and in particular stresses the importance of the literary component in the festivities. Almost a third of the pamphlet is devoted to the poems: instead of being relegated to an appendix they are presented as an essential part of the commemoration. It is as if a conscious decision has been made to showcase the academic and intellectual achievements of the students in order to establish the recently-founded English College as a highly motivated and fully operational institution within Spanish society.

It is particularly interesting to note that the festivities were in fact similar in 1592 and 1600 . This similarity was doubtless a deliberate attempt to remind the new king and his entourage of his father's profound political, religious, and financial commitment to the English Mission as well as to demonstrate that St Alban's had not forgotten its debt of gratitude to the late king. (It is worth noting that in the 1592 manuscript dedicated to the prince he was addressed as "maecenati," giving him the role of patron of the College.) The welcoming speech to Philip III and Queen Margaret reads:

We doe remember full well (most potent king) neyther shall we ever be able to forget, that most glorious and shining day, the brightest that ever was seene in this our Colledge, not with the presence of the Sunne \& his beames, but of your royall Magesty, and of the king your father of famous memory, to-gether with the renowned 
Lady the Infanta your sister; which day, this your presence so reneweth, and in so lively manner calleth it to memory, that it seemeth we see agayne that most glorious \& pious king memorable to all ages. ${ }^{46}$ (Rivers, $43-44$ )

After this speech, the students showed off their skills in the ten tongues, in this instance an explanatio of Psalm 20, verse by verse, with each explanation in a different language: Spanish, Hebrew, Greek, Latin, English, Welsh, Flemish, French, Italian, and, to replace the Scottish used eight years before, Cornish (doubtless because of the presence of a student from Cornwall). The commentaries in the more widely known languages are transcribed in their original languages (Spanish, Latin, Italian, and French), while the rest are merely summarized, sometimes with comments on the peculiarities of the language in question, such as the guttural sound of Hebrew or the perceived similarities between Cornish and Basque (Ortiz 37r-45r).

The pamphlet closes with two appended texts. The first is a report on the current situation of the College (Ortiz, 49v-53v), the second a speech addressed to the King's Councils by the Count of Puñoenrostro in which he lists reasons why support for the English Seminary should be maintained (Ortiz, 53v-6or). ${ }^{47}$ These texts share some similarities with those included in the final section of the Spanish 1592 pamphlet by Eclesal. All of them have a clear propagandistic value. Clearly the Count's efforts to secure royal assistance for the College are included with a Spanish audience in mind, most specifically one that could itself influence Philip III. However, the first of these propaganda texts seems also to be addressed to a wider readership:

Hoping that this relation may come to their [i.e., the students' parents] handes, translated into Inglish by your highnesse comaundement, I have thought good to adde some particular things of this Seminarie, for their advertisment of the state thereof. ${ }^{8}$ (Rivers, 65)

Curiously enough, here the Spanish author tries to adapt his text to an English readership, demonstrating that there was an awareness of the diverse interests of the two audiences. This takes us to the fourth difference between the 1592 and 1600 texts, that is, the nature of the translation. The English translation for Philip III's visit was undertaken by Francis Rivers, who was (he says) in Paris when he finished the rendering of the pamphlet in December 1600. 49

As "Thomas Eclesal" had before, Rivers says firstly "I was drawen with no little curiosety and desire, to read this booke when it came to my hands in the Spanish tongue" (Rivers, 3 ). He goes beyond textual or anecdotal curiosity, however, and gives other reasons for his interest, namely 
to gather the trewe causes, why the Spanish favor so much our Inglish Catholique fugetives, and what hartes they cary to their country, even these which, for Religion, leave it, to lyve in Seminaries abrode [ ... ] yf the good will of the King of Spaine and his people to our countrymen, and their correspondence to him and his, be founded in these honorable respects of conformity in Religion on the one side, and of piety and gratitude on the other, as by this relation may be gathered (far different from the surmises which by other wayes I have heard) me thinke the assurance of good meaninge, and knowen continuance of good will in them that were wont to be our friends though the late provoked to be our enemyes, should encourage us much to Peace. (Rivers 3-4)

As if to underline these concerns, the translation is addressed to "the Right Honorable the Lord of Hunsden. Lord Chamberlayn, and of her Majesty Privye Councel." Though the third baron was not as influential as his father had been, he was close to the queen and continued his family's patronage of drama. He was also committed to the Protestant regime, and so, through the device of a new dedication, the English version of the 1600 pamphlet was directed at a wider audience than English Catholics alone.

A further difference between the Spanish and English versions is that, unlike Eclesal's rendering of the 1592 pamphlet, here the translation was rather more literal; for example, Puñoenrostro's speech (intended for a Spanish readership) remains in place. This leads us to believe that he did not possess first-hand knowledge of what took place at St Alban's in August 1600, and that he had access only to those poems contained in the Spanish Relacion de la venida.

\section{Image and text in 1600}

A large quantity of poetry is included in the 1600 pamphlets, some 54 in all, which is, we are told, merely a selection from the 270 poems on the College's walls (Ortiz, $30 v$ ). Although the posters on display at the entrance contained welcome verses in nine different languages - thus anticipating the multilingualism of the oration of the ten tongues which would follow and reflecting the 1592 usage of diverse languages-the poems in this part of the celebration comprised a smaller linguistic range:

Among these verses there were but fewe in Spanish, because the recollection wherewith the schollers live doth not suffer them to have so much use of the language as is required for verses, and because this feast should only be theirs, as was intended by theire Magesties, whose meaning was to be received and feasted only by them..$^{50}$ (Rivers, 21) 
In fact, in this pamphlet only a Spanish poem is included, two octaves devoted to the first of St Alban's martyrs, Henry Walpole (Ortiz, 1or-v). The remainder are Latin texts. Their subject is typical of occasional poetry, directly connected with the celebration and the persons and institutions involved.

In the Spanish version describing Philip III's visit, there are as many poems as hieroglyphs; as in the 1592 pamphlet, the emblems are only described, and so no illustrations have survived, perhaps because of the desire to avoid any delay in printing. The type of imagery used in the hieroglyphs resembles that of the celebration of 1592, in which heraldry was an important source of symbolism, especially the king's coat of arms - lion, castle, eagle, pomegranate, golden fleece (in emblems $1-6,7,12-16$, and poems 24, 35) - or in the city's device, flames (in emblems 19, 20)..$^{1}$ This is emblem number six in Rivers's translation:

\footnotetext{
There was painted a castel of the armes of Castile, and upon one of the pinacles a lion watching; and upon an other was the golden fleece: and in the middest an eagle flying up to the clouds out of which came thunder and lightning, with this posie: turris inexpugnabilis, munita vigilantia, audacia, opibus.
}

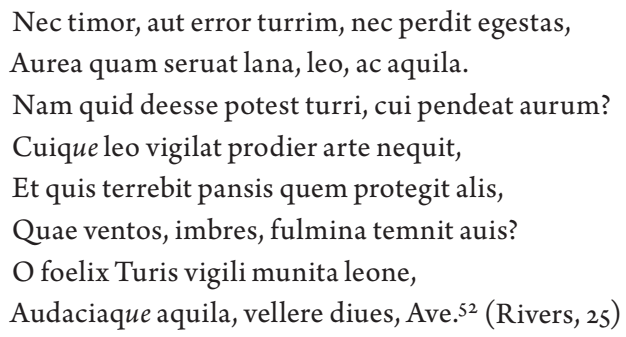

In the Spanish text, the heraldic elements conveying a symbolic meaning are marked graphically by using italics and capitalization. But besides this, in Ortiz's version superscript numbers appear on the words "Leon," "Tuson," and "Aguila," which correspond, respectively, to the ones on "vigilancia," "audacia," and "opibus," possibly in an attempt to show that in the illustration for this hieroglyph the Latin terms appeared above each of these images in phylacteries. This device seems to have been used to compensate for the absence of the verbal/visual conjunction which the hieroglyphs would have provided.

The symbolic elements are usually drawn from the emblematic tradition of Christian imagery: for example, the laurel tree (emblem 8 ), the vessel kept fast by anchors (emblem 17), Noah's ark (emblem 18), the sun (emblem 9, poem 31), the serpent or viper (emblem 22), or different types of flowers. It is not uncommon to find descriptions of emblems which closely resemble others in contemporary 
books. ${ }^{33}$ However, for the whole image (as it is described) to coincide with that in other hieroglyphs from other extant collections is very rare. What is more common is the use of widespread imagery applied to the specific occasion, for example, the circumstances of English Catholic exiles and their fight against heresy. In emblem 23, the Sun represents Philip III's strengthening and vivifying power which makes the lotus flower (symbolizing the English exiles) open up, with the light dissipating the darkness of the night (heresy, persecution). Night and day are frequently to be found in late medieval and early modern symbolism to represent faith vs. sin or orthodoxy vs. heresy, but some symbols do seem innovative, as in the case of the exotic lotus and its symbolic referent, the English students.

While these Christian or metaphorical images and symbols are more widely used in the emblems, and heraldic elements are usually common both in the hieroglyphs and poems, classical mythology seems to be consigned to the poems: Phaeton (poem 34), the river Lethes (36), Ceres (37), Memphis (39), Diana (39), Mars (43), Minerva (46), among others. Therefore, in the texts where there is no connection between the verbal and the visual, the symbolic meaning is conveyed through heraldic and classical mythology rather than by images connected to the Christian tradition. It is notable that in Spanish public festivities much of the allegorical symbolism was conveyed through mythology. ${ }^{54}$ In this case, though, the non-visual compositions are linked to the classical literary tradition, which the students learnt through their study of the humanities, in which, according to the Jesuit ratio studiorum, study of the classics was the basis of learning. ${ }^{55}$ Therefore, this display of classical erudition could well have been in tune with the students' intention of demonstrating their knowledge and abilities to the king and to future generations of readers, and their potential usefulness to the cause of Catholicism. The contrast between ephemeral and texts designed to last is thus displayed through the selection of different types of imagery.

Curiously enough, the differences between emblems and poems must have been significant for the English translator of the 1600 pamphlet, who in his version seems more interested in visual poetry, as the whole body of hieroglyphs is retained while all but three of the poems have been omitted. And, in this case, it is significant that the extant poems in the English version are an acrostic epigram dedicated to the Queen (Ortiz, 25r/Rivers 35-36) —where the visual element is obviously essential—and the final two compositions of the anthology, a "Virgilian enigma" and then the answer: 
Virgilian enigma

Tell me which is the land where there grow flowers named after monarchs and you will be great Apollo for me.

Answer

Look, Maro, the flowers that bear names of monarchs in their leaves grow in the Spanish orchards. The valley of Pincia [Valladolid] bears English flowers with the names of Marguerite and Philip written on them. These monarchs keep blood fresh for the martyrs, and it is preserved in purple roses, the blood shed by those who are to die for religion writes so many names in eternal books. ${ }^{56}$ (Rivers 36 )

Since in the rest of the pamphlet Rivers does not translate the Latin lines into English, ${ }^{57}$ he must have had a particular interest in these two poems. Yet, the challenge for a reader here is similar to the kind of active role required with commemorative literature, which juxtaposes words and images to produce complex hieroglyphs.

It must not go unremarked that both the 1592 and 1600 pamphlets in their English versions make a shorter selection of occasional poetry. Furthermore, in both cases, it is the emblems that are kept, and most of the poems omitted. What seems unquestionable is that visual poetry was preferred both by the author of the 1592 English pamphlet and by Francis Rivers as a way of exemplifying and representing how the English Catholic exiles in Spain carried out their most important celebrations. Indeed, it is particularly interesting how with this type of celebration they thanked the king for his support and demonstrated the fruitfulness of their education by employing typical Spanish baroque occasional poetry.

\section{The reception of the Vulnerata: pamphlets and poetry}

In September 1600, a few weeks after Philip III's visit to the College, a new celebration took place which would also result in a pamphlet. This concerned the reception of an image of the Virgin called the Vulnerata, and this second pamphlet, also by Antonio Ortiz, was entitled Recibimiento que se hizo en Valladolid a vna Imagen de nuestra Señora..$^{8}$ According to the Book of Accounts he was paid "forty reales" for writing both pamphlets. 59 No doubt this explains why quite frequently both relaciones are bound together.

The narrative begins with an introductory account explaining how, when the English navy reached Cadiz in 1596 and sacked the city, they removed a statue of the Virgin and Child from a church, mockingly adored it and then attacked it with their swords. ${ }^{60}$ When the students of St Alban's learned this, they decided to ask for the damaged statue so they could guard it in the College in compensation for what their fellow countrymen had done. The Countess of Santa Gadea, the owner of the image 
at that time, granted their wish, and this led to a great celebration to welcome the image to the city, similar to the ceremonies for public entries of important personages.$^{61}$ In the pamphlet the civic event is narrated in detail, and then a selection of the poetry follows. As in the 1592 pamphlet, the literary part of the festive occasion seems to be an appendix, rather than an integral part of it.

In spite of the similarities between the Vulnerata pamphlet and those for the royal visits, there must be a reason why the first two were printed both in English and Spanish and this one, though translated into English, was never published, surviving only in manuscript form: A relation of the solemnitie made in Spaine in the citie of Valiadolid the seaventh of September a 1600 for the receiving of an Ymage of our Blessed Ladye defaced by the English heretikes in Gades and placed by the English Catholickes in theire Seminaire. ${ }^{62}$ This could be explained by the fact that the events dealt not only with the political enmity between Spain and England-a confrontation that Rivers himself abhors, looking forward to a peaceful reconciliation-but also because it relates the shameful and irreverent behaviour of the English soldiers, which was perhaps too ignominious an act even in translation. But a perhaps more likely explanation is that the translation was too polemical to serve its purpose. It must be remembered that, in the account of the royal visit of 1600 , Francis Rivers had a wide English readership in mind; in the Vulnerata pamphlet the criticism of English politics and religion is direct, and perhaps would appeal to too narrow a target audience. Indeed, as we shall see there were attempts to tone down his work. ${ }^{63}$

The character of the English version could certainly account for the fact that it was never printed, as the translator expanded several passages to emphasize the condemnation of English politics and religion to an even greater degree than the Spanish version. The beginning of the narrative is a good example

For as much as the ende and institution of the English Seminaries, is to produce the reduction of there countrie to the true catholick and apostolick faith, which there forefathers enioyed soe many hundreth yeares before England was oppressed with these present heresies \& novelties of Luther and Calvine. ${ }^{64}$

The English text clearly emphasizes both the Catholic past and the heretical present of the English nation, though the author is careful to absolve the Queen herself from any direct responsibility for some of the more heinous "crimes." 65 The additions, which feature throughout the text, suggest a concern with the missionary purposes of the Seminary, attempting to reinforce the reader's feelings against heresy: the propaganda would therefore be geared specifically to committed English Catholics. On the other hand, though the translation tends to be literal, there are 
some interesting changes in the English text. Some data is altered-the date of a letter, the hour of a celebration - and the narrative of the events is recast, sometimes including details not contained in Ortiz's version. The author of the English translation may have been an eyewitness of the festivity of the Vulnerata reception, as it would appear he had the opportunity to amend some inaccuracies in the Spanish pamphlet. As for the anthology of poetry, the selection in the manuscript includes fewer compositions than Ortiz's version, which is explained in a final note: "The rest of the Latine and Spanish verses I omitt for brevitie sake, and desire the reader to take in good parte, that which with good meaning I haue here sett downe, and with desire to giue comfort without offence." 66

There are also more general differences between the events and the celebration narrated in the Vulnerata pamphlets and those of the 1592 and 1600 relaciones. Obviously, the latter focus on the royal visits and, although in the reception of the Vulnerata there was a royal presence (the Queen welcomed the Virgin to the College) the main interest in the narrative lies in the specific occasion, and its context. Whereas the royal visits were closed private events with only a few court, academic, and religious authorities allowed into the College - not even the royal guard entered the Seminary, according to the 1600 Relacion de la venida (Ortiz 29v) - the Vulnerata celebration had a civic and public character. The image of the Virgin was taken from the Cathedral to St Alban's College in procession through the city, and there "such an innumerable multitud of people was gathered to gether all a long the way to reverence the holy image and soe the procession, as the other parts of the citie were left desert and unpeopled." 67 The welcoming speech by one of the students was given on a dais outside the Seminary door and the majority of the poems were attached to the exterior wall of the building:

The church and porch of the English colledge were adorned with sumpteous hangings of cloth of gould which the Queenes maiestie had sent for that purpose, and all the forefront and walles of the Colledge were also covered with other hangings of silke, and upon them all alonge divers poems, epigrammes, and hieroglyphickes in prayse of our blessed Ladyes Nativitie, and of the solemnitie and receiving of this her image. 68

This is the only mention of the occasional literature found in the narrative. But the book of accounts provides further information. Someone was paid for writing poems to the Virgin ${ }^{69}$; it is not clear whether this person or persons were responsible for all the occasional literature, but it is reasonable to suppose that he was commissioned for the composition of the Spanish poems, while the Latin ones would have been written by the English students, for, as Ortiz himself had stated in his other 
pamphlet, they did not feel sufficiently confident to devise poetry in Spanish (Ortiz, $11 v$ / Rivers 21); nor, perhaps, on this occasion, in the absence of the king, was such a demonstration necessary.

The anthology of poetry in the Spanish pamphlet comprises 35 compositions: nine Latin hieroglyphs, four Latin poems, and 22 Spanish poems (mostly sonnets and octaves), though it is not clear whether the ratio of Spanish to Latin in this relación reflects that of the actual poetry for the festivity. The English manuscript retains the Latin compositions, probably not only for "brevitie sake" but also because of course these would need no translation for an English readership. The character of the poetic texts is, in general, similar to those of other pamphlets- the images of the hieroglyphs are merely described, no illustration is included-whereas the subject matter is mostly related to the specific occasion rather than to the situation of the English exiles. And it is precisely this thematic shift, this change of focus, that leads to the most important differences in the poems and hieroglyphs. The heraldic elements are almost absent, ${ }^{70}$ even in the poems dedicated to the Spanish Queen (poem 17) or to Valladolid (poem 28), and, of course, there are hardly any mythological references. All the imagery is drawn from the Bible or the liturgy, mostly Marian: rose (emblem 6), dove (emblem 8), lodestar (emblem 9); and there are several poems in which all of the titles, epithets, and appellations to the Virgin are combined:

On the epithets of the Moon given by St. Basil and St. Ambrose.

Notice that the two tercets of the sonnet explain the first two quatrains.

The Moon, mother of ${ }^{1}$ dew, is born

guide in the ${ }^{2}$ night, Lady of the ${ }^{3}$ sea

and breeder of the fertile 4 humour

pleasant temperance of sizzling ${ }^{5}$ summer

The one who moves and calms the ${ }^{6}$ wind at will

rules the ${ }^{7}$ time every hour

the one who is imitator of the bright ${ }^{8}$ Sun

and has for a mirror the gentle-flowing ${ }^{9}$ river.

Dew is ${ }^{1} \mathrm{God}$, night is ${ }^{2} \sin$

Church ${ }^{3}$ sea, humour ${ }^{4}$ divine love

${ }^{5}$ flesh is summer, wind the ${ }^{6}$ soul

7life is time, ${ }^{8} \mathrm{Christ}$ the crystalline

sun of my heart, 9 gentle river

where Moon and Sun look at themselves if it is calm. ${ }^{71}$

In the original Spanish poem, the usage of superscript numbers differs from the hieroglyph in Philip III's visit mentioned earlier. These numbers are not a way 
of compensating for the absence of the image; rather, they are an interpretive support for the sonnet. What surprises in this case is that the poem itself provides the exegesis of its own metaphors, with the note after the title informing the reader that all the conceits in the two quatrains are explained in the tercets. Therefore, the numbers are an additional aid to understanding the imagery of the poem. This tells us something about the intended audience; it suggests, moreover that this type of device was believed to be necessary to grasp the meaning of some of the more intricate poems and images. ${ }^{72}$ However, this example is exceptional and although it must be acknowledged that some of the Spanish poems seem to have a less learned character than the Latin ones, others make considerable use of conceit and metaphor.

The festivity of the Vulnerata placed the College not only in a strategic position in international politics, but also at the centre of Spanish society. For the first time, their audience was not limited to the king and his retinue, but the seminarists were able to enact an expiation of the affronts committed by their nation for a popular audience. And they did so by making use of literature and image, in a display which reinforced the cultural, religious, and political dimension of the College, an identity which in turn was disseminated in the accounts of these events.

THE PAMPHLETS WE have discussed are currently the only pamphlets known to us that relate to the celebrations at St Alban's. The records show, however, that there were other festive occasions at the College. Several entries in the books of accounts mention payment for the composition of hieroglyphs and poems, props for performances, as well as payments to painters and singers, ${ }^{73}$ and it seems almost certain that either a member of the royal family or other important personalities paid visits to the College. ${ }^{74}$ In 1605 the Lord Admiral came to Valladolid to ratify the peace treaty between England and Spain; invited by Creswell to visit the College, he finally chose to decline: the new political situation placed St Alban's in a new, more uncertain position, which made it something of an embarrassment for both the Spanish and the English crowns. Though in 1615 king Philip III came once more to the College, this visit was not recorded in any pamphlet. This may have been for lack of funds, due to the College's less secure situation, or even perhaps because the students, though unfamiliar with theatrical tradition, decided to perform a play which turned out to be a disaster, as is recorded in the Annals of the College. ${ }^{75}$ But it seems certain that the College's heyday was behind it.

The pamphlets from St Alban's College and the royal visits they describe confirm the degree of care and attention paid to all aspects of commemorative literature 
by the English exiles in their mission. The poems provide a unique example of the combination of English and Spanish cultural usages, while the pamphlets make clear the adoption of diverse perspectives, tuned in to the sensibilities of their audiences and the purposes of the College.

In general terms, it is intriguing to note that the tone of the pamphlets becomes less strident with each royal visit, and this is a subtle response to a changing political environment. The pamphlet for the visit of Philip II in 1592, when the Anglo-Spanish conflict was at its height, was far more polemical in tone than that adopted to describe his son's visit in 1600, when Elizabeth I's reign was evidently drawing to a close. This shift is nicely illustrated in the Vulnerata English manuscript, written the same year, where the stated aim is to give "comfort without offence." Although the Vulnerata Spanish pamphlet makes forceful criticisms of England's Protestant regime, it may be for precisely this reason that the decision was taken not to publish it in English, despite the fact that a translation had been completed in manuscript. Times were changing, and with the signing of a peace between the two countries in 1604, the English College could no longer take the Spanish Crown's enmity towards England for granted, nor even its continued patronage. The fiasco of the 1615 play seems to represent the loss of the assuredness which had characterized its relations with the Spanish authorities. Doubtless changes in cultural taste had their part to play, but with the improvement in Anglo-Spanish relations, and the greater toleration afforded to English Catholics towards the end of James's reign and during that of his son, the ill-fated Charles Stuart, the Golden Age of the production of occasional literature at the English College had ended; but not without leaving powerful testimony of the importance of commemorative literature to early modern culture.

\section{NOTES}

1. This article is the result of research carried out with the help of funding from two research projects, Fondos documentales de la biblioteca y archivo del colegio de los Ingleses de Valladolid (va 084/04, Junta de Castilla y León, years 2004-2006) and Relaciones institucionales Valladolid/Inglaterra: Documentos selectos del Archivo y Biblioteca del Colegio de los Ingleses de Valladolid (ss. XVI-XX) (vAo04Ao7, Junta de Castilla y León, years 2007-2009). It will be supplemented by a forthcoming edition of the pamphlets and manuscripts that are the subject of this article: Berta Cano Echevarría and Ana Sáez Hidalgo, The Fruits of Exile: Emblems and Pamphlets from the English College at Valladolid (Valladolid: ACSA series $\mathrm{n}^{\circ}$ 2, forthcoming). Also by Cano and Sáez, 
"Emblemas para un príncipe: el manuscrito 2492 de la Biblioteca Nacional," Imagen y Cultura. La interpretación de las imágenes como historia cultural. vi Congreso de la Sociedad Española de Emblemática (Valencia: Biblioteca Valenciana, forthcoming); and "The Two Faces of the Virgin, or the Double Rendering of a News Pamphlet" (forthcoming).

2. Apart from monographs on specific figures such as Robert Persons, Albert Loomie's indefatigable research has provided most of the data available for the study of English exiles in Spain: see The Spanish Elizabethans: The English Exiles at the Court of Philip II (New York: Burns \& Oates, 1963), and Toleration and Diplomacy: The Religious Issue in Anglo-Spanish Relations, 1603-1605 (Philadelphia: American Philosophical Society, 1963). Allison and Rogers's catalogue of printed sources for the study of English Counter-reformation lists all the contemporary works-literary and non-literaryboth in English and other languages: see A. F. Allison and D. M. Rogers, The Contemporary Printed Literature of the English Counter-reformation between 1558 and 1640. Vol. I: Works in languages other than English. Vol. II: Works in English (Aldershot: Scolar Press, 1989-94). William MacCabe's work on Jesuit Theatre is also of significance: An Introduction to the English Jesuit Theatre (St. Louis: Institute of Jesuit Sources, 1983). More recently Alison Shell dedicates two chapters to exile literature, in Catholicism, Controversy and the English Literary Imagination, 1558-1660 (Cambridge: Cambridge University Press, 1999); while essays on Continental English Catholics can be found in Catholic Culture in Early Modern England, ed. Ronald Corthell, Frances E. Dolan, Christopher Highley, and Arthur F. Marotti (Notre Dame, IN: The University of Notre Dame Press, 2007). See also Arthur F. Marotti, Religious Ideology and Cultural Fantasy: Catholic and Anti-Catholic Discourses in Early Modern England (Notre Dame, IN: University of Notre Dame Press, 2005), p. 290.

3. Other English Seminaries had already been established in Italy (Rome, 1576) and the Low Countries (Douai, 1568) but the political and religious instability in the Netherlands led to the search for a safer base. After St Alban's was founded, two more Colleges opened in Spain-St Gregory in Seville (1593) and St George in Madrid (1610) - as well as in Portugal (Lisbon, 1593) and France (St Omer, 1594). See M. E. Williams, St Alban's College, Valladolid: Four Centuries of English Presence in Spain (London, New York: C. Hurst-St. Martin's Press, 1986), pp. 19-33.

4. Elizabeth I, "A declaration of great troubles pretended against the realm by a number of seminary priests and Jesuits sent and very secretly dispersed into the same to work great treason under a false pretence of religion with a provision very necessary for the remedy thereof" (London, 1591). See Paul Hughes, ed., Tudor Royal Proclamations (New Haven-London: Yale University Press, 1969), vol. 3, p. 88.

5. Williams, pp. 7-8.

6. Despite all these efforts, libels and accusations of heresy and espionage circulated whenever there were conflicts with the English Colleges. See José Ramón Fernández Suárez, “Joseph Creswell: al servicio de Dios y de su Majestad Católica (1598-1613)," 
ES. Revista de Filología Inglesa 8 (1978), pp. 69 and 72-73; and Loomie, Spanish Elizabethans, pp. 222-23.

7. In A Relation of the King of Spayne's receiving in Valladolid in the English College of the same town in August last past of this year (Antwerp: A. Conincx, 1592; reprint: Aldershot: Scolar Press, 1977), it is described how the number of students had increased, explaining "that the late proclamation set out by the Queene in November last, against this Seminarie, did first of all geve them notice thereof” (p. 13).

8. Joseph Cresswell, Historia de la vida y martirio que padeció en Inglaterra este año de 1595 el P. Henrique Valpolo Sacerdote de la Compañía de Jesús que fue embiado del Colegio de los ingleses de Valladolid y ha sido el primer mártyr de los seminarios de España: con el martyrio de otros quatro sacerdotes los dos de la misma Compañía y los otros dos de los Seminarios (Madrid, 1596).

9. Hughes, p. 88.

10. Sydney Anglo, Spectacle, Pageantry and Early Tudor Policy (Oxford: Clarendon Press, 1969), pp. 326-39.

11. José Ma Díez Borque, Verso e Imagen: Del Barroco al Siglo de las Luces (Madrid: Calcografía Nacional, 1993), pp. 129-32.

12. J. Simón Díaz, "La poesía mural del Siglo de Oro: su proyección en Universidades y Colegios," in Estudios sobre el Siglo de Oro. Homenaje a Francisco Yndurain (Madrid: Editora Nacional, 1984), pp. 479-99.

13. Jorge Báez de Sepúlveda, Relación verdadera del recibimiento que hizo la ciudad de Segovia a la magestad de la reyna nuestra señora doña Anna de Austria ... , ed. Sagrario López Poza and Begoña Canosa Hermida (Madrid: Fundación Don Juan de Borbón, 1998), p. 24.

14. Leonard Tennenhouse, "Strategies of state and political plays. A Midsummer Night's Dream, Henry IV, Henry v, Henry viII," in Alan Sinfield and Jonathan Dollimore ed., Political Shakespeare: Essays in Cultural Materialism (Manchester: Manchester University Press, 1985), pp. 109-128, p. 125.

15. William Leahy, Elizabethan Triumphal Processions (Aldershot: Ashgate, 2005).

16. On the question of how different audiences responded to public processions, A. A. Bromham looks at how the "moment" of the event signified in several ways, which depended on the positions of different audiences, and their proximity to the event itself, since some spectators enjoyed more privileged vantage points than others, in “Thomas Middleton's The Triumphs of Truth: City Politics in 1613," The Seventeenth Century 10 (1995), pp. 1-25. Our focus concerns how in turn, in printed form, these texts appealed to different kinds of audience, English and Spanish.

17. The only traceable original copy of the Relation of the King is preserved in Lambeth Palace Library. A facsimile edition has been published together with another anonymous treatise also attributed to Persons, The Generall rubriques of the breviarie (1977). For citations in the text and in notes below, the Relation of the King will appear in parentheses as "Creswell." 
The whole journey is recounted in another pamphlet of the time: Hendrick Cock, Jornada de Tarazona hecha por Felipe II en 1592 pasando por Segovia: Valladolid, Palencia, Burgos, Logroño, Pamplona y Tudela (ca. 1598), ed. Alfredo Morel Fatio and Antonio Rodriguez Villa (Madrid: M. Tello, 1879). On the celebrations carried out in Valladolid during Philip II's stay, see Javier Castán Lanaspa, "Fiestas que ofreció la villa de Valladolid a Felipe II en el año 1592," Boletín del Seminario de Estudios de Arte y Arqueología 62 (1996), pp. 387-94.

18. The title page states that it was "wryten by an Inglish Priest of the same College," but there were other priests who could well have written the account. It is also stated that the author has only been in the College for a few months (Creswell, 6), a fact which rules out Persons, who had been in St Alban's since its foundation. The author uses the first person to include himself in the narration of events: "praesentlie I have some charge and exercise in this place to over looke the builders" (Creswell, 11); yet it speaks of Persons in the third person, for example: "oftentymes I have heard F. Persons saie ..." (Creswell, 59).

19. Joseph Creswell wrote several works: Exemplar Literarun ad Cecilium (sive Burleigh) (1592), under the pseudonym "John Perne," against Elizabeth's proclamation of November 29, 1591; Información a la ciudad de Sevilla, por parte del Colegio Ingles de la misma ciudad (1604); Vando y leyes del rey Jacobo de Inglaterra contra la fe católica con su respuesta, $y$ advertencias al letor (1611; John Floyd transl.: A proclamation with a briefe answere, 1617). See also note 6 on Cresswell, and Glyn Redworth, "Books Not to be Sold: the Costs of Printing in the Golden Age," Bulletin of the Society for Renaissance Studies 23 (2005), pp.17-26.

20. In Antwerp a colony of English Catholic exiles took advantage of the existence of Plantin's printing press to publish most of their propaganda treatises. See the catalogue for the exhibition: Antwerp, Dissident Typographical Centre: The Role of Antwerp Printers in the Religious Conflicts in England ( $16^{\text {th }}$ century) (Antwerp: Plantin-Moretus Museum-Snoeck-Ducaju \& Zoon, 1994).

21. Hughes, p. 92.

22. The best known of these is Robert Persons's Responsio ad Edictum (1592); Joseph Creswell also wrote a series of fictional letters by an English traveller about continental reactions to the Edict just before he moved from Rome to Valladolid (Exemplar literarum, 1592). Other responses were composed by Robert Southwell (1600) and Thomas Stapleton (1592). Victor Houliston includes this Relation of the King of Spaines receiving in Valliodolid among the responses but attributes it to Persons: see Houliston's “The Lord Treasurer and the Jesuit: Robert Person's Satirical Responsio to the 1591 Proclamation," Sixteenth Century Journal 32:2 (2001), pp. 383-401; and Catholic Resistance in Elizabethan England: Robert Person's Jesuit Polemic, 1580-1610 (Aldershot: Ashgate, 2007), pp. 67-68.

23. See M. Canessi Acevedo, Historia de Valladolid (1750), ed. Celso Almuiña (Valladolid: Grupo Pinciano, 1996); L. Hicks, "Father Persons, S.J., and the Seminaries in Spain,” The Month (1931), pp. 410-17; Albert Loomie, Spanish Elizabethans; Williams; 
Federico Eguíluz Ortiz de Latierro, Robert Persons, "El Architraidor" (Madrid: Fundación Universitaria Española, 1990).

24. However, Joseph Gillow managed to identify the names of each of these students, who frequently used aliases, in A Literary and Biographical History or Bibliographical Dictionary of the English Catholics. From the Breach with Rome, in 1534, to the Present Time (London: Burns \& Oates, 1885), vol. 5, p. 279.

25. We are grateful to Peter Harris for having pointed out its existence to us. For short references, the label "Prince ms" will be used for this text.

26. "My Lord Treasorer is like to have work enoughe for his daies and for his son and nephues also after him ... The wicked and violent persecutors inheritance shal be to have his children slain, and his nephues beg their bread, as also the rest of his generation for his sake brought to destruction" (Creswell, pp. 60-61).

27. "The Relation of an English Priest written to a gentleman of his country exiled in Flanders for being a Catholic" [our translation] (Madrid: Pedro Madrigal, 1592). This text will be referred to as "Eclesal". In cases where the English and Spanish texts do not correspond we provide our translation and so indicate this. Otherwise the translations are drawn from the original sixteenth-century texts. All the Spanish passages are translated into English in the text and the original included in the notes.

28. “Traduzida de inglés en castellano, por Tomás Eclesal cavallero Inglés”. Once again there is the problem of authorship and attribution as "Eclesal" is clearly a pseudonym. The fact that he is called a gentleman, and not a priest, and that he is said to be of English origin are two possible clues to the writer's identity. Two candidates have been suggested: according to some library catalogues, the author is Cristóbal López SJ (1552-1617), known for his life of Pedro de Ribadeneyra (Vida del Padre Pedro de Ribadeneyra, 1612) who, in turn, wrote the life of Father Ignatius of Loyola (Vida del P. Ignacio de Loyola, 1586). Surprisingly enough, Ribadeneyra was also the censor who inspected the Spanish translation of the 1592 Relacion. But more plausibly Albert J. Loomie identified the author as the English merchant Thomas James, a close acquaintance of Persons who had settled in Spain and who worked on behalf of English Catholic exiles, the most important task being to take newly ordained priests back to England incognito. Loomie demonstrates that contemporaries recognized the pseudonym "Eclesal" as referring to James and it was indeed used by him in other documents. See Loomie, “Thomas James: The English Consul of Andalucia 1556-c1613," Recusant History 11 (1971), pp. 165-78.

29. The need to publish parallel bilingual texts which require certain ideological, religious, or political adjustments for different national groups has been one of the points analyzed by Polysystemic studies. See Itamar Even-Zohar, Polysystem Studies (Special issue), Poetics Today 11 (1990); Philippe Codde, "Polysystem Theory Revisited: A New Comparative Introduction,” Poetics Today 24:1 (2003), pp. 91-126; Gideon Toury, Descriptive Translation Studies and Beyond (Amsterdam \& Philadelphia: John Benjamins, 1995); José Lambert, “Translation, Systems and Research: The Contribution of Polysystem Studies to Translation Studies Publication,” TTR: Traduction, Ter- 
minologie, Redaction: Études Sur le Texte et Ses Transformations 8:1 (1995), pp. 105-52. Their target-oriented approach to translation in the early days of the Tel-Aviv School of Poetics and Semiotics led to an important change of focus in translation studies.

Manuel J. Gómez Lara, in his paper "Genealogical Devices: Heraldry and Politics in Elizabeth Tudor's Funeral Procession" (18 $8^{\text {th }}$ International Conference of the Spanish and Portuguese Society for English Renaissance Studies, 2007), has studied the varying perspectives on a single event that can be observed in accounts by different narrators of Elizabeth I's funeral; according to his analysis, there are clear ideological biases underlying these disparities.

30. "De los que ogaño van del Colegio Inglés a la Misión de Inglaterra” (Eclesal, p. 79).

31. Our translation. "Miré todas las diez lenguas, y escogí las que acá me parece se podrán fácilmente entender, como son, fuera de la castellana, que todos entienden, la latina, y la italiana: y assí me pareció poner en estas tres algunos de los hieroglíficos, y poesías que en ellas huvo; siguiendo en esto el consejo del sacerdote que escrivió en inglés" (Eclesal, fol. 57r-v).

32. "Castillo de la Yberia celebrado / Por tus armas en todo el ancho suelo, / Que a mil bárbaras gentes han domado, / levantando tu nombre al alto cielo; / Otras más fuertes armas has labrado / De litras, de piedad, de santo zelo, / Que sube a armarse dellas con tal gana / La juventud católica Anglicana” (Eclesal, fol. 6or).

33. "De lexas tierras a encender venimos / Las hachas en las llamas celestiales / Para volver después donde salimos, / Y consumir los fuegos infernales” (Eclesal, fols. 61v62r).

34. "El Áquila Real os da licencia / Palumbas blancas que en su Iberio estado, / Cojáis el trigo de virtud y ciencia, / Que tiene como en hera limpio echado" (Eclesal, fol. 63r).

35. "Soberano Pastor, miras al ganado/ En mano y dientes de animales fieros?/ Si miro; y rato ha ya que estoy parado / Escuchando balar a mis corderos./ Pues como assi los dexas en el prado/ Que los maten los lobos carniceros?/ Si; porque assi muriendo cobran vida/ Y dan a su Patria destruyda" (Creswell, p. 57; Eclesal, fol. 62v, where the text is punctuated differently, and the last line reads "Y a su patria le bueluen la perdida").

36. Eclesal 63v: "Pero ni ha avido comodidad, ni tiempo para ello."

37. This selection of poems can also be found in manuscript form in the Biblioteca Nacional, Madrid (MS 6001). The volume, entitled Ramillete de Flores o Collección de varias cosas curiosas ("Bunch of Flowers or Collection of Curiosities") is, as its title indicates, a compilation of a diversity of materials, among which we find the literal transcription of the poems preceded by a short introduction about their provenance and circumstances of composition. The only poem missing in this selection is the logogriph, which most certainly appeared unreadable for the copyist.

38. Biblioteca Nacional de Madrid (MS 2492).

39. The manuscript is in octavo $(22,5 \times 16,8 \mathrm{~cm})$, a size that does not seem appropriate for visual poetry. 
40. The emblems are cited after the facing pages in which they appear, thus including the reference both to the image and to the text.

41. Antonio Bernat Vistarini and John T. Cull, Enciclopedia de emblemas españoles ilustrados (Madrid: Akal, 1999), emblems 50 and 64.

42. See Antonio Ortiz, Relacion de la venida de los Reyes Catholicos, al Collegio Ingles de Valladolid, en el mes de Agosto Año de 16oo. Y la collocación y fiesta hecha en el mesmo Collegio, de una Ymagen de Nuestra Señora maltratada de los hereges (Madrid: Andrés Sánchez, 1600). In the Book of Accounts it is specified: "Dy a uno estudiante de fuera por escribir dela venida de los Reyes y de Nuestra Señora doze Reales" ("I gave twelve reales to an outside student for writing on the reception of the Monarchs and Our Lady"), Archives of St Alban's College [ACSA] Book of Accounts no 1 (from 1598 to 1614), 66v (October 1600). A search for Ortiz in the University of Valladolid records leads us to think that either he did not receive his BA or he was studying at some other institution, perhaps at San Ambrosio, the Jesuit college in Valladolid where the English students took their courses.

43. Francis Rivers, A Relation of the Solemnitie wherewith the Catholike Princes K. Philip III and Quene Margaret were receyved in the English Colledge of Valladolid the 22. of August. 160o. Written in Spanish by Don Ant. Ortiz and translated by Frauncis Rivers and dedicated to the Right Honourable the Lord Chamberlayne (Antwerp: A. Conincx, 1601; reprint: Ilkley: Scolar Press, 1977). The abbreviated reference for the English version will be "Rivers," and for the Spanish "Ortiz," in parentheses.

44. On the circumstances of this visit and all the civic celebrations and festivities, see Antonio Cabeza Rodríguez, Margarita Torremocha Hernández, and Ricardo Martín de la Guardia, "Fiesta y política en Valladolid. La entrada de Felipe in en el año 1600," Investigaciones históricas 16 (1996), pp. 77-87. We are grateful to Margarita Torremocha for her kind and enlightening help in historical matters and, especially, for her generous advice on the study of baroque festivities.

45. This fact must not go unremarked, as it is one of the many connections between the two royal celebrations: the Infanta Isabel Clara Eugenia had visited the Seminary in 1592, accompanying her father Philip II and her brother, the king-to-be Philip III. It seems clear that Ortiz's dedication to her is an attempt to underline the parallels between the visits. Robert Persons himself had proposed the candidacy of Infanta Isabel for the English throne in A Conference about the Next Succession of the Crowne of Ingland (1594), under the pseudonym R. Doleman. See Hicks; and José María Ruiz Ruiz, "Robert Persons, S.J. (1546-1610) y su obra más polémica: A Conference about the Next Succession to the Crowne of England.” Es. Revista de Filología Inglesa, 7 (1977), pp.117-215.

46. "Porque nos acordamos (Rey invictíssimo) y nunca nos olvidaremos, de aquel día, que amaneció alegre, y ilustríssimo a este nuestro Seminario; no con los rayos del Sol, sino con el resplandor de Vuestra Majestad y del Rey su padre, y de la claríssima Infanta su hermana: del qual día nos pone este presente un vivo retrato, y nos parece que vemos aquel gran Rey, memorable en todos los siglos” (Ortiz, fol. 34r). 
47. According to Puñoenrostro, there are several grounds for sustaining the English mission in Spain, viz., piety (Ortiz, fols. 54v-56v), Christian nobility (Ortiz, fols. $56 \mathrm{v}-$ $58 \mathrm{r}$ ) and opportunity (Ortiz, fols. 58r-6or).

48. "Fiado de que esta relación llegará a sus manos traduzida en lengua Inglesa por medio de Vuestra Alteza, he querido añadir algunas cosas deste seminario de donde reciban consuelo" (Ortiz, fol. 49v).

49. "So I take my leave from Paris the 2. of December, 1600 ", is the end of the dedicatory of Rivers's translation. Since English Catholic exiles were constantly changing their names and aliases, it seems plausible to connect this name with an "Anthony Rivers," one of the aliases of Henry Floyd, who studied in Valladolid and was an informant connected with John Blackfan and Robert Persons: see Francis Edwards, "Identifying Anthony Rivers SJ," Notes and Queries (1994), pp. 62-63. Although the records do not indicate Floyd's location by the end of 1600 , his active role as a recusant, and his first-hand knowledge of Valladolid, lead to us consider him the possible author of the English translation. However, there are several other references to persons named "Rivers" related to English Catholics. One of them acted as courier for Creswell and is mentioned in a letter by a subsequent English ambassador to Spain, Charles Cornwallis, who was angered by the constant intrigues of the Jesuits and Rivers's role in them (Charles Cornwallis to the Earl of Salisbury [January 10, 1607]; see Sir Ralph Winwood, Memorials of affairs of state in the reigns of Q. Elizabeth and K. James I: Collected (chiefly) from the original papers of the Right Honourable Sir Ralph Winwood [London: T. Ward, 1725], pp.368-69).

50. "Entre estas poesías avía pocas Españolas, porque se pretendió que toda la fiesta fuesse fruta deste su plantel de su Magestad, y como tal le fuesse más sabrosa: y los estudiantes con el recogimiento que se guardan, no tienen comodidad para aprender tan aventajadamente nuestra lengua, como fuera menester para esto." (Ortiz, fol. 11v)

51. In this case the numbering of poems and emblems is correlative to its position and does not correspond to the page number.

52. "Estava pintado el Castillo de las armas de Castilla, y sobre una de las torres un ${ }^{1}$ Leon velando, y sobre la otra el ${ }^{2}$ Tuson, en medio una ${ }^{3} \mathrm{Aguila}$ volando entre las nuves, truenos y relampagos, y tenia este retulo. Turris inexpugnabilis, munita ${ }^{1}$ vigilancia, ${ }^{2}$ audacia, ${ }^{3}$ opibus" (fols. 13v-14r). The Latin reads "impregnable tower, fortified watchfulness, audacity, and strength," respectively.

The Latin poem can be translated as follows: "Neither fear, nor deceit nor poverty can ruin the tower defended by the golden wool, a lion and an eagle. What can be missing in the tower where gold hangs? What is guarded by the lion cannot be besieged treacherously or deceitfully. Who will terrify the one who is protected by the stretched wings of a bird that disdains winds, rains and rays? O happy tower protected by the watching lion, the eagle's audacity and rich by the fleece's wealth, Ave" (our translation). 
53. The motif of the laurel tree as a symbol of security (emblem 8) can be traced back to Alciato (Bernat Vistarini \& Cull, emblem 494); the sun eclipsing the moon is interpreted in religious terms as Faith defeating Heresy (emblem 9; Bernat Vistarini \& Cull, emblem 1521). Quite a traditional image, originally biblical, is that of the ship tossed by a tempest and secured by the anchor of faith (emblem 17; Bernat Vistarini \& Cull, emblem 1155). Deer were sometimes used as symbols for government: in emblem 19, that meaning is reinforced by the fact that the animals are "carying fire vpon their hornes taken from the armes of this cite of Valladolid", using both their horns and the fire to keep away "todes, serpentes, bartes and owles", images of sin and heresy; similar emblems would be used to represent justice and the enemy of sin (Bernat Vistarini \& Cull: emblems 368 and 369 ).

54. F. Rodríguez de la Flor and E. Galindo Blasco, Política y fiesta en el Barroco (Salamanca: Ediciones Universidad de Salamanca, 1994); Teatro y fiesta: del Siglo de Oro en tierras europeas de los Austrias: Exposición. Real Alcazar, Sevilla 11 abril-22 de junio (Madrid: Sociedad Estatal para la Acción Cultural Exterior, 2003).

55. Eusebio Gil, et al., ed., El sistema educativo de la Compañía de Jesús. La "Ratio Studiorum" (Madrid: Universidad Pontificia de Comillas, 1992); Carmen Labrador Herraiz, El sistema educativo de la Compañía de Jesús: la "ratio studiorum": estudio históricopedagógico (Madrid: Universidad Pontificia de Comillas, 1992).

56. "Ad enigma Virgilianum: Dic quibus in terris inscripti nomina regum / Nascantur flores, \& eris mihi magnus Apollo.

Responsio: Ecce Maro, hesperiis flores nascuntur in hortis, / Qui regum in foliis nomina scripta gerunt. / Margaris incisos nomen, nomenque Philippi / Anglorum Flores Pincia vallis habet: / Martyribus reges hi nutriuere cruorem, / Et se purpureis in seruere rosis, / Qui cruor effusus pro relligione tuenda, / Scribet aeternis nomina tanta libris." (Ortiz, p. 28v / Rivers p. 36)

57. In the poetic anthology, Rivers translated only the titles of the compositions and the descriptions of the hieroglyphs, leaving Latin poems in their original version. By contrast, in the section devoted to the orations of the ten tongues, some of the speeches that in Ortiz's version are transcribed in the original language-namely, the Latin, French, and Italian discourses - are rendered into English by Francis Rivers.

58. Madrid: La Tina, 160o. The abbreviation "Vulnerata" will be used to refer to this edition, and "Vulnerata Ms" for its English version.

59. "De escribir la venida delos Reyes y de la Ymagen de nuestra señora, quarenta reales" (ACSA, Book of Accounts 1, October 1600).

6o. This is the reason why the Bishop of Valladolid chose the name "Santa María Vulnerata" for the statue, "bycause no Spanish word was found propper and significant which, with decensye declared the case he called it in Latine Sancta Maria Vulnerata, and sayed that in Spanish they might use nuestra Señora Injuriada" (Vulnerata Ms, fol. $64 \mathrm{v})$. For a detailed account of the Sack of Cádiz and the story of the Vulnerata, see Ismael Bengoechea, Nuevos relatos del asalto inglés a Cádiz en 1596 (Cádiz: Real Aca- 
demia Hispanoamericana de Cádiz, 1996); and Javier Burrieza Sánchez, "Reparando las heridas: el nacimiento de una devoción de 'Contrarreforma,'” Brocar. Cuadernos de Investigación Histórica 26 (2002), pp. 107-150.

61. M. L. Lobato and B. J. García García, La fiesta cortesana en la época de los Austrias (Valladolid: Junta de Castilla y León, Consejería de Educación y Cultura, 2003); Margarita Torremocha Hernández, "Diversiones y fiestas en Valladolid durante el Antiguo Régimen," in Valladolid. Historia de una ciudad. Actas del Congreso Internacional de Historia de Valladolid, 7 al 11 de octubre de 1996 (Valladolid: Ayuntamiento de Valladolid, 1999), vol. 2, pp. 491-510.

62. The manuscript, written in one hand, is now preserved at the English College Rome Archives (ms vec 1422). No date is indicated, however both the handwriting and the circumstances surrounding it make us think that it must date from the early years of the seventeenth century. This document was kept at St Alban's until 1769, when, two years after the expulsion of the Jesuits, the Council of State had it sent to Madrid; five years later the Rector of the College succeeded in recovering it, but finally it ended up in Rome. We are grateful to Peter Harris for having pointed out the existence of this manuscript to us.

63. For instance, Antonio Ortiz explains that the choice of the Nativity day for the Vulnerata celebration was a way of compensating for the English Queen's suppression of that festivity and the fact that, instead, English people celebrated the birthday of Elizabeth (Vulnerata, fols. 5v-6r); the English translation stresses its disapproval of this, for it meant "canonizing her alive which the Catholicke church doth not use nor permitt with any saincte how holy so ever he be" (Vulnerata Ms, fol. 63r).

64. Vulnerata Ms, 49r. Our italics show the passages added by the English translator. "Como el fin de los Seminarios ingleses es la reduzión de Inglaterra al gremio de la Santa Iglesia Católica" (Vulnerata, fol. 2r). In the English text, "these present heresies" has been deleted and in a later revision "the detestable opinions and novelties" inserted instead.

65. While the Spanish text emphasizes Elizabeth's heretical behaviour, the tone is softened in the English version, for example in the following: "The Countesse sent it [the image] ... not only to repayre and recompence the iniuries committed by those faythlesse hereticks against this sacret image in Gades, but also to blott out the impietie of other there fellows in England who with notable follie and flatery and no doubt without consent or knowledg of her maiestie haue razed out in ther kalenders obscured the name and memorie of this most happie feast" (Ms Vulnerata, fol. 53r; additions in italics).

66. Vulnerata MS 7ov.

67. Vulnerata MS, 55v. "Tan innumerable concurso de gente ... a ver la processión, que quedó despoblado el resto de la Ciudad” (Vulnerata, fol. 9v). This type of public religious celebration in the streets had become quite fashionable in Spain in the last quarter of the sixteenth century, according to J. Simón Díaz in La poesía mural en el Madrid del Siglo de Oro (Madrid: Artes Gráficas Municipales, 1977), pp. 11-13. 
68. Vulnerata MS, 56 r. "Estava la Yglesia y portada del Colegio inglés ricamente adereçada con unas colgaduras de tela de oro, que la Reyna nuestra Señora embió a este fin, y todo el lienço de las paredes, de fuera del Colegio, entoldado de seda con muchas, y varias, no menos ingeniosas que devotas poesías Españolas y Latinas, en reverencia desta Santa Imagen, y de la Natividad de nuestra Señora, y del Recibimiento que se hazía la Reyna, y a la Imagen, y de la alegría de su venida a esta ciudad, y Colegio” (Vulnerata, fol. 1or).

69. ACSA, Book of Accounts 1, p. 61r, 63r.

70. The only case of the use of heraldic elements is hieroglyph no. 4, in which the Virgin appears, stepping on a dragon's head bearing the arms of England. Here there is a clear similarity with the representation of killing the dragon-St George, of course, being England's patron saint.

71. Our translation. "De los epítetos de la luna, que le dan S. Basilio y S. Ambrosio. Nota que los dos tercetos del soneto explican a los dos quartetes [sic] primeros. Nace la Luna madre del ${ }^{1}$ rocio, / guía en la ${ }^{2}$ noche, y de la ${ }^{3}$ mar Señora, / y del ${ }^{4}$ humor fecundo engendradora, / templança amena del ardiente 5 estio, / La que mueue, y serena a su alvedrio / el ${ }^{6}$ ayre, rige el ${ }^{7}$ tiempo de ora en ora, / la que es del claro ${ }^{8}$ sol imitadora, / y tiene por espejo al manso ${ }^{9}$ río. / Rocío es ${ }^{1}$ Dios, la noche es el ${ }^{2}$ pecado, / la ${ }^{3}$ Iglesia mar, humor amor ${ }^{4}$ Diuino, / la carne es el ${ }^{5}$ estío, el ayre el ${ }^{6}$ alma, / La 7 vida el tiempo, ${ }^{8}$ Christo el christalino / sol de mi coraçón, ${ }^{9}$ río espojado / do luna y sol se miran si está en calma” (Vulnerata, fol. 42v).

72. The linguistic difficulties, and the subsequent need for translation, are commented on in connection with the Latin welcome sermon: some in the audience were given a printed Spanish version of it "to understand it better when it was pronounced" (Vulnerata Ms, fol. 6or; Vulnerata, fol. 14v).

73. Until 1623, there are references in the Books of Accounts 1 and 2 (ACSA) to hieroglyphics $(1597-8,1601,1609)$, poetry $(1598,1602)$, comedies $(1598,1615)$, painters $(1598,1610$, $1615,1620,1623)$, and singers $(1609,1611,1613,1615,1620,1623)$ as ways of celebrating different events, ranging from royal visits to the canonization of Ignatius of Loyolaan occasion which was commemorated in most Jesuit Colleges, as recorded in some pamphlets. See Antonio de Salazar, Fiestas que hizo el insigne colegio de la Compañía de Jesús en Salamanca a la beatificación del Glorioso Patriarcha S. Ignacio de Loyola, con los sermones y poesías que uvo en alabanza del Santo (Salamanca: viuda de Artus Taberniel, 1610).

74. According to the books of accounts, there were extraordinary expenses to commemorate events and other occasions: the queen attended a celebration in 1601 (perhaps commemorating the first year of the Vulnerata at St Alban's); in April 1602 the Condestable visited the College; in December 1607 the bishop ordained some priests of the Seminary; in 1623 some songs and perhaps poetry were prepared for the possible visit of Prince Charles on his way back from Madrid, though there is no certainty that this event took place. 
75. "Hoc anno rex invictissimus Philippus III., cum hanc civitatem pertransisset, invisit etiam ab alumnis quadam comedia quae tumultuario opere congesta et ex improviso exhibita, cum adolescentuli vix bene quod erat cujusque digessissent, pessime successit, et non parum opinioni quae de hoc Collegio mentibus hominum insiderat derogavit. Cui infelicitati successit alia multo major ut nihil ad cumulum miseriae huic Collegio hoc anno inflictae deesse videretur" (John Blackfan, Annales Collegii Anglorum Vallisoletani [London, 1899], p. 92). 